\title{
Factors Affecting the Salinity Intrusion at the Paddy Field in Thua Thien Hue Province, Vietnam
}

\begin{abstract}
Background: Several coastal regions in Vietnam have been suffered from salinity intrusion as a consequence of global climate change. However, there are limited studies on saline intrusion in Vietnam. This paper aimed to investigate the salinity intrusion of water and soil samples in paddy fields along Tam Giang lagoon, Thua Thien Hue province and clarify the factors affecting the salinity level.

Methods: We measured the salinity concentrations (EC, Electrical conductivity) of water and soil samples in paddy fields at different distances $(400,600,800,1000$ and $1200 \mathrm{~m})$ from Tam Giang lagoon. The multiple regression analysis was performed to figure out the factors affecting the salinity concentrations.

Result: The salinity concentrations of water were assessed as $48 \%$ high saline $\left(10-25 \mathrm{dS} \mathrm{m}^{-1}\right), 34 \%$ moderately saline $\left(2-10 \mathrm{dS} \mathrm{m}^{-1}\right)$, $2 \%$ slightly saline $\left(0.7-2 \mathrm{dS} \mathrm{m}^{-1}\right)$ and $15 \%$ non-saline $\left(<0.7 \mathrm{dS} \mathrm{m}^{-1}\right)$. As for surface soil in paddy field, $14.3 \%$ moderately saline $(4-8 \mathrm{dS}$ $\left.\mathrm{m}^{-1}\right), 35.4 \%$ slightly saline $\left(2-4 \mathrm{dS} \mathrm{m}^{-1}\right)$ and $50.3 \%$ non-saline $\left(0-2 \mathrm{dS} \mathrm{m}^{-1}\right)$ were measured. A significantly positive correlation was found between salinity concentrations of water and soil $(n=175, r=0.886, p<0.01)$. The distances from salinity sources, Tam Giang lagoon and shrimp pond, were major factors affecting the salinity concentrations. The paddy fields near Tam Giang lagoon and shrimp pond have higher salinity concentrations compared to those areas close to the residential area. The surface water in the paddy field within $1000 \mathrm{~m}$ from the salinity source was assessed as saline that might harm the paddy soil and rice production. The results of this study provide highly useful information for local policymakers and farmers about the status of salinity intrusion in paddy land.
\end{abstract}

Key words: Paddy field, Phu Xuan commune, Salinity intrusion, Tam Giang lagoon.

\section{INTRODUCTION}

Soil salinity is one of the most crucial environmental problems affecting developing countries in arid and semiarid regions (Mahesh et al. 2019). The increasing salinity of coastal deltas can be attributed partly to the rising of sea levels and the increasing frequency of drought events as a result of global climate change (Baten et al. 2015; Wassmann et al. 2004). Many coastal regions in Vietnam have been suffered from complex salinity intrusion. Various studies on salinity intrusion have been conducted in the most vulnerable regions under climate change effects including Vietnamese Mekong (Ha et al. 2020; Nhung et al. 2019; United Nation, 2020; Wassmann et al. 2004), Red River Delta (Ca et al. 1994; Yen et al. 2017). However, salinity situations in the areas of central coastal Vietnam have been received less attention in the literature (Trang et al. 2019). Among the provinces in the north-central coastal region, agricultural soil in Thua Thien Hue province is seriously affected by soil salinization (Lam et al. 2014). In this region, about 2500 ha of agricultural lands adjacent to the Tam Giang lagoon, which is the biggest lagoon in Southeast Asia (approximately 22,000 ha), are saline (Dan et al. 2006). Phu Vang district of Thu Thien Hue province has been considered as one of the most vulnerable regions to climate change effects including sea-level rise, drought and salinity intrusion. Saline intrusion is the main cause affecting agricultural production, many rice production areas cannot be cultivated and have to turn to aquaculture. Therefore, research on the
'University of Agriculture and Forestry, Hue University, 102 Phung Hung str., Hue, Vietnam.

${ }^{2}$ School of Biotechnology, Tan Tao University, Tan Duc E. City, Duc Hoa, Long An, 850000, Vietnam.

3University of Sciences, Hue University, 77 Nguyen Hue str., Hue, Vietnam.

Corresponding Authors: Nguyen Thanh Dien and Nguyen Phuc Khoa, School of Biotechnology, Tan Tao University, Tan Duc E. City, Duc Hoa, Long An, 850000, Vietnam. University of Agriculture and Forestry, Hue University, 102 Phung Hung str., Hue, Vietnam. Email: dien.nguyenthanh@ttu.edu.vn; npkhoa@hueuni.edu.vn

How to cite this article: Khoa, N.P., Dien, N.T., Ngu, N.H. and Trung, H.D. (2021). Factors Affecting the Salinity Intrusion at the Paddy Field in Thua Thien Hue Province, Vietnam. Indian Journal of Agricultural Research. DOI: 10.18805/IJARe.A-630.

Submitted: 13-03-2021 Accepted: 02-12-2021 Online: 25-12-2021

current state of saline intrusion is really necessary for the development of agriculture in the context of climate change in the central region and Thua Thien Hue province.

The effect of soil salinity on rice production has been reported by many authors (Funakawa et al. 2000; Lam et al. 2014). The impact of saline water intrusion on the productivity of rice farms has been addressed by Trang et al. (2019). The yields of salt-tolerant rice cultivars had positive correlations with traits of plant height, panicles per plant, panicle weight and dry biomass which directly affected the 
rice yield (Lam et al. 2020; Elayaraja and Sathiyamurthi, 2020). Minh et al. (2020) indicated that potential salinity is one of the factors affecting rice cultivation in Southern Vietnam. However, the salinity relationship between water and soil at the paddy field has not been determined yet. Furthermore, there has been no investigation on the effects of saline sources on the paddy fields. Therefore, our objectives of this study are to (1) measure simultaneous water and soil samples for salinity concentration, (2) investigate the factors affecting the salinity level of the paddy field, (3) build the map presenting the level of salinity.

\section{MATERIALS AND METHODS}

\section{Study site}

Phu Vang is a low-lying coastal plain within the Tam Giang lagoon system and located in the Northeast of Thua Thien Hue province, with a total natural area of 27,824 ha, covering $5.53 \%$ of the total natural area of Thua Thien Hue province. In this study, we surveyed the Phu Xuan commune (from $16^{\circ} 46^{\prime} 12^{\prime \prime}$ to $16^{\circ} 53^{\prime} 42^{\prime \prime} \mathrm{N}$ and $107^{\circ} 65^{\prime} 32^{\prime \prime}$ to $\left.107^{\circ} 73^{\prime} 40^{\prime \prime} \mathrm{E}\right)$ in the northeast of Phu Vang district. The soil conditions are mainly sea sand, dune soil and sea sand changed by rice cultivation with the mechanical components of over $70 \%$ being coarse sand. Most of the agricultural land is used for rice cultivation and aquaculture. Due to being adjacent to the Tam Giang lagoon system with a length of $11.5 \mathrm{~km}$, the saline intrusion has affected agricultural production, especially rice production. Many rice land areas have to be converted to aquaculture, cultivated other crops such as potatoes and melons, or not cultivated.

\section{Experimental design}

We collected the surface water and soil for salinity measurement. In this study, we aimed to investigate the effect of salinity source and seasonal change of salinity concentration in the paddy field.

Considering the boundary of the studying site, we collected samples at the 5 different designated locations (PX1, PX2, PX3, PX4 and PX5). For each location, 5 distant plots (approximately $400 \mathrm{~m}, 600 \mathrm{~m}, 800 \mathrm{~m}, 1000 \mathrm{~m}$ and $1200 \mathrm{~m}$ ) from Tam Giang Lagoon were sampled for salinity measurement (Fig 1). The first plot $(400 \mathrm{~m})$ of the survey location is adjacent to the Tam Giang lagoon and ends with paddy land near the residential area. Besides, at each location, the water samples from Tam Giang lagoon and shrimp pond were also collected for salinity measurement (Fig 1). The survey was conducted once a month from March to September 2020.

\section{Salinity measurement}

The presence of salts enhances the ability of a solution to conduct an electrical current and therefore high EC (Electrical Conductivity) values indicate high salinity levels. $E C$ values of water samples were directly measured at the field using Hana HI 993310 (Hana Instrument, Inc, Romania). EC values of soil samples were measured at the laboratory using the "EC 1:1 w/v" method. Soil samples collected from the surface horizon were air-dried and gently grounded to pass through a 2-mm mesh sieve. The soil salinity was determined by mixing an aliquot of a sample with deionized water, at a soil/liquid ratio of $1: 1(\mathrm{w} / \mathrm{v})$ (Zhang et al. 2005; Matthees et al. 2017). In brief, a 10-g sample of air-dried soil was pretreated with $10-\mathrm{ml}$ deionized water $(10 \mathrm{ml})$ at room temperature $\left(25^{\circ} \mathrm{C}\right)$. After 30 minutes the electrical conductivity is measured and the levels of salt in the soil are determined. A glass electrode was used to measure the value for each sample.

\section{Data collection and statistical analysis}

The meteorological conditions at sampling sites are collected by the local meteorological office. In this study, the data on

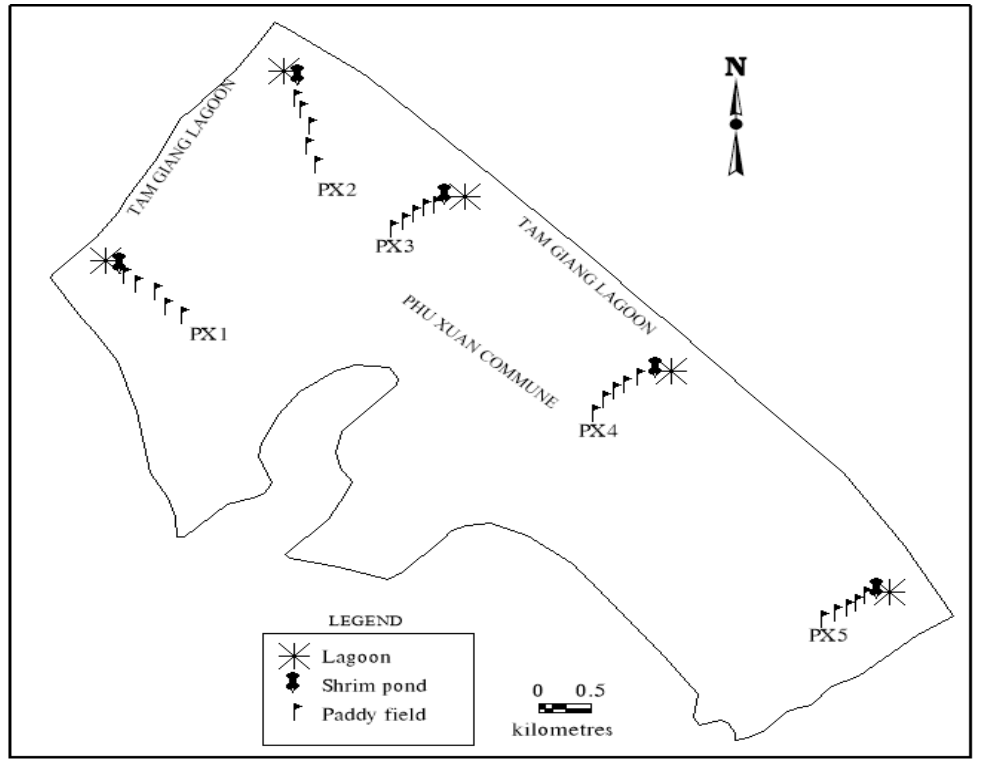

Fig 1: Sampling map at Phu Xuan commune of Phu Vang district, Thua Thien Hue Province. 
monthly temperature $\left({ }^{\circ} \mathrm{C}\right)$, rainfall $(\mathrm{mm})$, humidity $(\%)$ and evaporation rate $(\mathrm{mm})$ are obtained.

We performed multiple regression analysis to figure out the factors influencing the salinity using the equation:

$\mathrm{S}=\mathrm{a}+\mathrm{b}_{1} \cdot$ distance $+\mathrm{b}_{2} \cdot$ temperature $+\mathrm{b}_{3} \cdot$ rainfall $+\mathrm{b}_{4}$. humidity $+b_{5} \cdot$ evaporation $+\varepsilon$

Where

$\mathrm{S}$ is the concentration of salinity $\left(\mathrm{dS} \mathrm{m}^{-1}\right) ; \varepsilon$ is an error term that follows a normal distribution with mean 0 and variance $\sigma^{2} ; a$ is an intercept; $b_{1}, b_{2}, b_{3}, b_{4}$ and $b_{5}$ are regression coefficients. The model was run by the Stata 15 software (StataCorp LP, Texas, USA).

\section{Mapping by GIS technique}

Mapping the salinity level was conducted by the Natural Neighbor Interpolation method (Sibson, 1981) using ArcGIS 10.3 (Esri Institute, Inc., USA). To determine the natural neighbor of an interpolation point $\mathrm{x}$, one can imagine this point is virtually inserted into the Voronoi diagram. This virtual insertion modifies the original Voronoi diagram and creates a new Voronoi cell $V(x)$, a set of points that are closer to $x$ than to any known $x_{i}$. The $V\left(x_{i}\right)$ share edges with $\mathrm{V}(\mathrm{x})$; consequently, sample points of $\mathrm{x}_{i}$ are a natural neighbor of $x$. Weighted averaging of the sample values for these natural neighbors gives the interpolated value at $x$. The simple natural neighbor interpolation is defined as the following formula:

Where

$$
f(x)=\frac{\sum_{i} a_{i} * f\left(x_{i}\right)}{\sum_{i} a_{i}}
$$

$a_{i}$ is the overlap area corresponding to the know data site $x_{i}$. The term overlap area refers to the area shared by $V\left(x_{i}\right)$ and $\mathrm{V}(\mathrm{x})$. The overlap polygon is called the second-order Voronoi cell (Sambridge et al. 1995). If the sample point $x_{i}$ lies outside of the convex hull of all known sample points, the overlapping polygon is un-bounded and ai in equation 1 is infinite. Therefore, only points that lie inside the convex hull of known sample point $x_{i}$ can be interpolated to mapping.

\section{RESULTS AND DISCUSSION}

\section{Level of water salinity in Tam Giang Lagoon and shrimp pond}

To understand the salinity intrusion from the lagoon to the paddy field, we first measured the salinity levels of surface waters at the lagoon and shrimp pond (former paddy field) from March to September 2020. The mean (standard deviation) values of water at the lagoon and shrimp pond were $23.0 \pm 1.88 \mathrm{dS} \mathrm{m}^{-1}$ and $26.8 \pm 1.6 \mathrm{dS} \mathrm{m}^{-1}$, respectively. These values were classified as very high saline according to salinity standards by FAO (1992).

Table 1: Salinity concentrations of water and soil in the paddy field.

\begin{tabular}{|c|c|c|c|c|c|c|c|c|c|c|c|c|c|c|c|}
\hline \multirow{2}{*}{ Plot } & \multirow{2}{*}{$\begin{array}{l}\text { Distance to } \\
\text { Lagoon (m) }\end{array}$} & \multicolumn{8}{|c|}{ Monthly water $\left(\mathrm{dS} \mathrm{m}^{-1}\right)$} & \multicolumn{4}{|c|}{ Monthly soil $\left(\mathrm{dS} \mathrm{m}^{-1}\right)$} & \multirow[b]{2}{*}{8} & \multirow[b]{2}{*}{9} \\
\hline & & 3 & 4 & 5 & 6 & 7 & 8 & 9 & 3 & 4 & 5 & 6 & 7 & & \\
\hline PX1.1 & 400 & 14.8 & 15.9 & 22.4 & 22.7 & 20.7 & 22.5 & 14.2 & 3.2 & 5.6 & 1.9 & 2.7 & 4.7 & 4.7 & 3.3 \\
\hline $\mathrm{PX} 2.1$ & 400 & 14.9 & 16.2 & 22.8 & 19.2 & 21.2 & 20.9 & 14.4 & 3.7 & 4.0 & 2.5 & 5.4 & 5.2 & 4.0 & 3.5 \\
\hline PX3.1 & 400 & 14.4 & 15.6 & 19.1 & 23.1 & 21.1 & 23.4 & 14.7 & 3.6 & 4.3 & 5.3 & 6.4 & 5.9 & 2.5 & 4.1 \\
\hline PX4.1 & 400 & 13.9 & 21.2 & 22.3 & 22.7 & 19.5 & 19.7 & 14.2 & 2.0 & 4.1 & 6.5 & 2.8 & 3.9 & 1.7 & 4.1 \\
\hline PX5.1 & 400 & 14.3 & 16.3 & 22.6 & 23.5 & 15.5 & 19.3 & 14.0 & 3.5 & 3.0 & 4.8 & 5.7 & 1.9 & 4.8 & 4.5 \\
\hline PX1.2 & 600 & 12.0 & 13.4 & 14.3 & 16.3 & 17.5 & 14.8 & 12.6 & 1.7 & 2.2 & 3.3 & 3.4 & 3.3 & 4.0 & 2.8 \\
\hline PX2.2 & 600 & 12.6 & 13.9 & 14.9 & 15.5 & 18.2 & 18.0 & 13.3 & 3.0 & 3.3 & 3.6 & 3.5 & 4.4 & 3.4 & 3.2 \\
\hline PX3.2 & 600 & 12.3 & 12.9 & 14.7 & 16.7 & 18.3 & 16.8 & 14.1 & 3.1 & 3.6 & 4.1 & 4.6 & 5.1 & 3.7 & 3.8 \\
\hline PX4.2 & 600 & 12.2 & 18.3 & 14.4 & 16.1 & 15.0 & 14.4 & 13.4 & 3.1 & 3.4 & 4.7 & 4.2 & 3.4 & 3.7 & 3.5 \\
\hline $\mathrm{P} \times 5.2$ & 600 & 12.6 & 13.5 & 14.8 & 16.7 & 13.7 & 14.8 & 13.3 & 3.3 & 2.7 & 4.1 & 4.1 & 2.9 & 3.5 & 3.7 \\
\hline PX1.3 & 800 & 9.1 & 11.1 & 10.4 & 9.3 & 9.2 & 11.7 & 9.2 & 0.4 & 2.9 & 2.2 & 2.4 & 2.0 & 0.9 & 1.9 \\
\hline PX2.3 & 800 & 8.5 & 8.9 & 9.7 & 10.6 & 8.9 & 11.1 & 8.9 & 2.3 & 2.8 & 1.0 & 2.4 & 2.3 & 1.2 & 2.3 \\
\hline PX3.3 & 800 & 10.0 & 11.4 & 9.1 & 11.4 & 11.6 & 8.9 & 11.4 & 2.0 & 3.2 & 2.5 & 3.2 & 3.2 & 2.1 & 3.2 \\
\hline PX4.3 & 800 & 10.5 & 8.0 & 12.2 & 10.6 & 8.6 & 10.6 & 11.0 & 1.8 & 2.0 & 2.5 & 2.0 & 2.3 & 1.9 & 2.8 \\
\hline PX5.3 & 800 & 7.3 & 8.0 & 8.4 & 7.8 & 9.2 & 7.5 & 7.9 & 2.0 & 1.8 & 2.3 & 2.3 & 1.4 & 2.8 & 2.3 \\
\hline PX1.4 & 1000 & 3.0 & 9.1 & 2.3 & 2.3 & 3.2 & 3.9 & 2.2 & 0.7 & 1.0 & 0.7 & 1.2 & 1.0 & 0.4 & 0.5 \\
\hline PX2.4 & 1000 & 4.1 & 4.5 & 3.3 & 5.3 & 4.3 & 8.8 & 3.3 & 0.8 & 0.7 & 0.6 & 1.0 & 0.8 & 1.5 & 0.6 \\
\hline PX3.4 & 1000 & 5.3 & 6.0 & 3.0 & 4.1 & 5.6 & 3.4 & 3.9 & 0.5 & 0.6 & 0.8 & 1.1 & 1.0 & 1.1 & 0.6 \\
\hline PX4.4 & 1000 & 8.4 & 5.4 & 7.0 & 7.2 & 4.1 & 8.4 & 7.0 & 0.5 & 0.6 & 0.9 & 1.1 & 0.9 & 1.3 & 0.5 \\
\hline PX5.4 & 1000 & 5.2 & 5.7 & 4.3 & 4.4 & 3.4 & 5.2 & 4.3 & 0.4 & 0.0 & 0.0 & 0.6 & 0.1 & 1.0 & 0.8 \\
\hline $\mathrm{PX} 1.5$ & 1200 & 0.6 & 3.3 & 0.0 & 0.0 & 0.0 & 0.0 & 0.5 & 0.1 & 0.0 & 0.0 & 0.0 & 0.0 & 0.4 & 0.0 \\
\hline PX2.5 & 1200 & 0.2 & 0.2 & 0.0 & 0.0 & 0.0 & 1.9 & 0.3 & 0.1 & 0.8 & 0.0 & 0.0 & 0.0 & 0.0 & 0.1 \\
\hline PX3.5 & 1200 & 0.0 & 0.2 & 0.2 & 0.0 & 0.0 & 0.0 & 1.5 & 0.0 & 0.0 & 0.1 & 0.0 & 0.0 & 0.0 & 0.4 \\
\hline PX4.5 & 1200 & 1.6 & 0.1 & 0.0 & 3.0 & 0.2 & 3.1 & 4.6 & 0.1 & 0.2 & 0.0 & 0.1 & 0.1 & 0.2 & 0.0 \\
\hline PX5.5 & 1200 & 0.3 & 0.7 & 0.0 & 0.6 & 0.4 & 0.6 & 1.2 & 0.3 & 0.0 & 0.0 & 0.0 & 0.0 & 0.0 & 0.0 \\
\hline
\end{tabular}




\section{Level of salinity in surface water and soil samples in the paddy field}

We measured simultaneous water and soil samples at different distances from Tam Giang Lagoon from March to September 2020 to clarify the distance effect and seasonal change of salinity concentration. Table 1 presents the salinity concentrations of surface water and soil in the paddy field at Phu Xuan commune. The mean values of salinity concentrations of water and soil were $9.7 \mathrm{dS} \mathrm{m}^{-1}$ (range: $0-$ $23.5 \mathrm{dS} \mathrm{m}^{-1}$ ) and $2.1 \mathrm{dS} \mathrm{m}^{-1}$ (range: 0-6.5 $\mathrm{dS} \mathrm{m}^{-1}$ ), respectively. In another survey at Phu Vang district in 2015, the average salinity levels of soils were $0.9 \mathrm{dS} \mathrm{m}^{-1}$ (fluctuated from 0.43 to $1.41 \mathrm{dS} \mathrm{m}^{-1}$ ) (Linh et al. 2017). The salinity intrusion on the paddy field in 2020 was wider than that intrusion in 2015 conducted by Linh et al. (2017). The possible reasons were that extreme conditions with high temperatures and serious drought starting from February to September 2020.

Table 2: Classification of salinity level on water simple.

\begin{tabular}{lcc}
\hline \multirow{2}{*}{ Classification } & \multicolumn{2}{c}{ Salinity concentration of water $\left(\mathrm{dS} \mathrm{m}^{-1}\right)$} \\
\cline { 2 - 3 } & $\begin{array}{c}\text { Standard } \\
\text { FAO }(1992)\end{array}$ & $\begin{array}{c}\text { No. of sample in this } \\
\text { study }(\mathrm{n}=175)\end{array}$ \\
\hline Non-saline & $<0.7$ & 27 \\
Slightly saline & $0.7-2$ & 4 \\
Moderately saline & $2-10$ & 60 \\
Highly saline & $10-25$ & 84 \\
Very high saline & $25-45$ & 0 \\
\hline
\end{tabular}

The surface waters in paddy field were classified as $48 \%$ high saline (10-25 dS $\left.\mathrm{m}^{-1}\right), 34 \%$ moderately saline (2$\left.10 \mathrm{dS} \mathrm{m}^{-1}\right), 2 \%$ slightly saline $\left(0.7-2 \mathrm{dS} \mathrm{m}^{-1}\right)$ and $15 \%$ nonsaline $\left(<0.7 \mathrm{dS} \mathrm{m}^{-1}\right)$ (Table 2$)$. The moderately and high saline water (from a distance of 400-1000 m) may cause the salinity intrusion potential on paddy land. From Table 1, the non-saline or slightly saline waters are distributed from a distance of $1200 \mathrm{~m}$ from the lagoon. The salinity level of water in the paddy field was relatively high (moderately saline) ranging from 8.3 to $10.8 \mathrm{dS} \mathrm{m}^{-1}$ (mean $\pm \mathrm{sd}$ : $9.7 \pm 6.8$ $\mathrm{dS} \mathrm{m}^{-1}$ ) and varies from month to month (Table 3) with highest in June and lowest in March. The main reason for the lowest salinity in March was that the farmer supplies the freshwater for rice production. Thus, a certain amount of freshwater diluted the salinity concentration at this time. Meanwhile, the highest salinity concentration in June was connected with high temperature $\left(29.9^{\circ} \mathrm{C}\right.$ ) and less rain $(14 \mathrm{~mm}$ ) (Table 3 ). It was also the time when the paddy field lacks water and suffers from drought, which was a favorable condition for salinity to penetrate the soil and water.

The surface soils in paddy field were assessed as $14.3 \%$ moderately saline $\left(4-8 \mathrm{dS} \mathrm{m}^{-1}\right), 35.4 \%$ slightly saline (2-4 $\mathrm{dS} \mathrm{m}^{-1}$ ) and $50.3 \%$ non-saline (0-2 dS m $\mathrm{m}^{-1}$ ) (Table 4). Grattan et al. (2002) suggested that if the salinity concentration of soil is larger than $1.9 \mathrm{dS} \mathrm{m}^{-1}$, the rice growth will be adversely affected. The soil in this survey was classified as $53 \%$ was affected by salinity $\left(>1.9 \mathrm{dS} \mathrm{m}^{-1}\right)$ and $47 \%$ wasn't affected by salinity $\left(<1.9 \mathrm{dS} \mathrm{m}^{-1}\right)$. The affected salinity soils $(>1.9 \mathrm{dS}$ $\left.\mathrm{m}^{-1}\right)$ were mostly distributed near the salinity source with

Table 3: Monthly salinity concentrations in surface water, soil and corresponding meteorological conditions.

\begin{tabular}{|c|c|c|c|c|c|c|c|}
\hline Item & $\begin{array}{l}\text { March } \\
n=25\end{array}$ & $\begin{array}{c}\text { April } \\
n=25\end{array}$ & $\begin{array}{l}\text { May } \\
n=25\end{array}$ & $\begin{array}{l}\text { June } \\
n=25\end{array}$ & $\begin{array}{c}\text { July } \\
n=25\end{array}$ & $\begin{array}{l}\text { August } \\
n=25\end{array}$ & $\begin{array}{c}\text { September } \\
n=25\end{array}$ \\
\hline Salinity concentration in water $\left(\mathrm{dS} \mathrm{m}^{-1}\right)$ & 8.3 & 9.6 & 10.1 & 10.8 & 10.0 & 10.8 & 8.6 \\
\hline Salinity concentration in soil ( $\left.\mathrm{dS} \mathrm{m}^{-1}\right)$ & 1.7 & 2.1 & 2.2 & 2.4 & 2.2 & 2.0 & 2.1 \\
\hline Temperature $\left({ }^{\circ} \mathrm{C}\right)$ & 25.7 & 24.8 & 29.5 & 29.9 & 29.6 & 28.9 & 28.6 \\
\hline Rainfall (mm) & 47.8 & 217.4 & 35.6 & 14.0 & 48.2 & 153.4 & 225.1 \\
\hline Humidity (\%) & 87 & 89 & 81 & 76 & 77 & 81 & 82 \\
\hline Evaporation rate (mm) & 50.6 & 36.0 & 80.2 & 98.7 & 108.5 & 72.2 & 72.3 \\
\hline
\end{tabular}

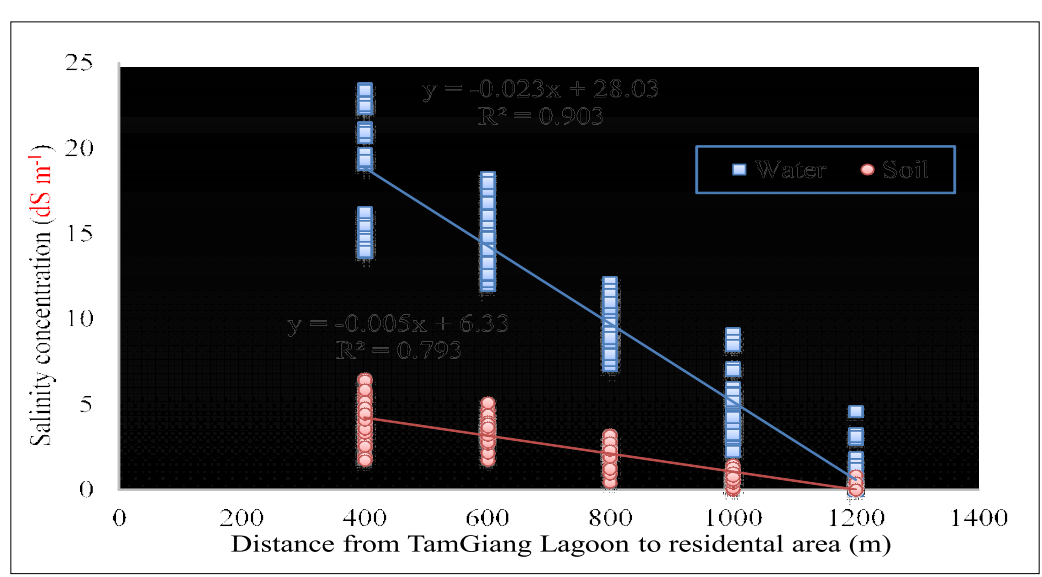

Fig 2: Relationship between salinity concentration and salinity source. 


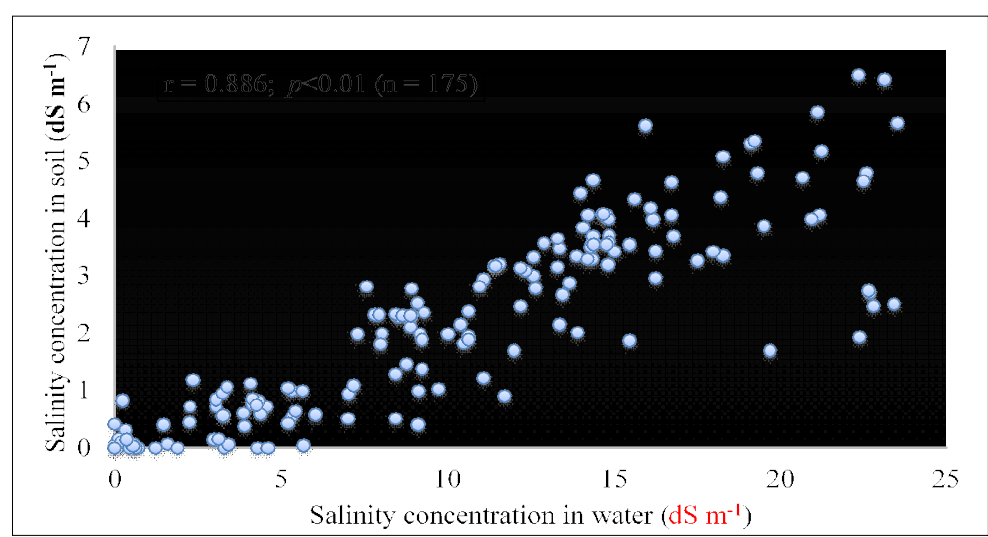

Fig 3: Pearson correlation between salinity concentrations in water and soil.

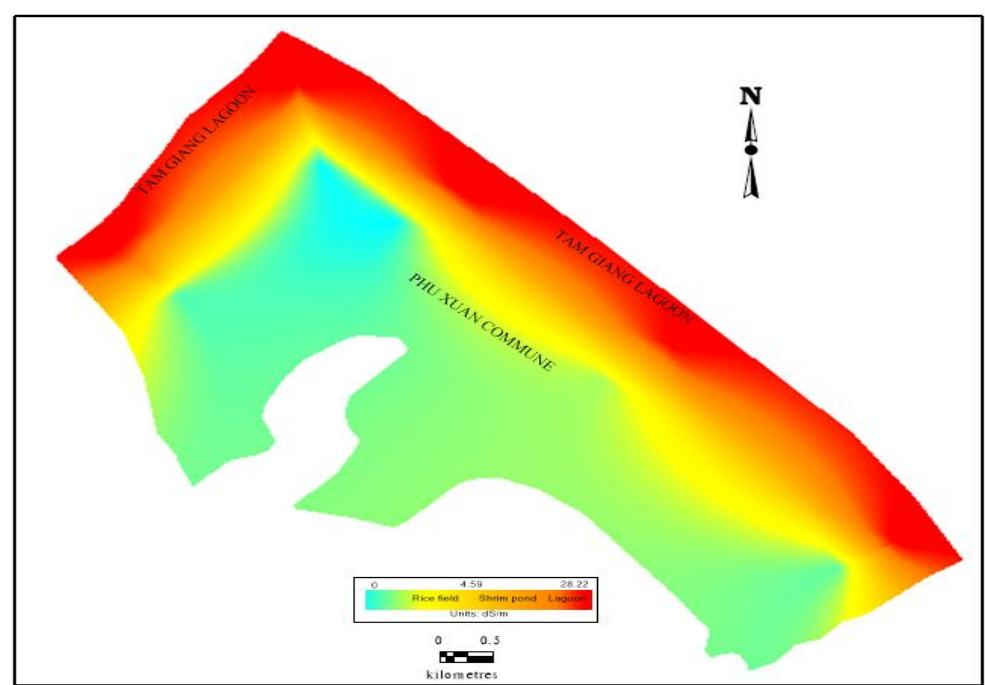

Fig 4: Mapping the salinity levels of Soil in Phu Xuan commune.

distances of 400,600 and $800 \mathrm{~m}$ from the lagoon. Salinity levels of paddy soil from April to September (ranging from 2.0 to $2.4 \mathrm{dS} \mathrm{m}^{-1}$ ) were higher than that of March (1.7 dS m$\left.{ }^{1}\right)$ (Table 3). The reason for higher salinity levels of paddy soils in April - September was that the hot and dry weather increases the salinity intrusion into the soil.

Fig 2 presents the significantly inverse relationship between salinity concentrations of water $(r=-0.95 ; p<0.01)$ and soil $(r=-0.89 ; p<0.01)$ and distance of salinity source. This means that the paddy fields near Tam Giang Lagoon and shrimp pond have higher salinity concentrations compared to those areas close to the residential areas. The cause of the saline intrusion is determined by the water level in Tam Giang lagoon that penetrates the paddy soil according to the irrigation system. Furthermore, in the summer, a high amount of water evaporates from the sea and lagoons and then condenses in the paddy fields. Besides, there are many activities of domestic wells in residential areas absorbing groundwater in the soil. As a result, saltwater in the aquifer may penetrate deeper into the soil.

Fig 3 shows that water salinity has a significantly positive correlation with soil salinity $(r=0.886, p<0.01)$. As a result,
Table 4: Classification of salinity level on soil simple.

\begin{tabular}{lcc}
\hline \multirow{2}{*}{ Classification } & \multicolumn{2}{c}{ Salinity concentration of soil $\left(\mathrm{dS} \mathrm{m}^{-1}\right)$} \\
\cline { 2 - 3 } & $\begin{array}{c}\text { Standard FAO (1988) } \\
\text { and Abrol et al. (1988) }\end{array}$ & $\begin{array}{c}\text { No. of sample in } \\
\text { this study }(\mathrm{n}=175)\end{array}$ \\
\hline Non-saline & $0-2$ & 88 \\
Slightly saline & $2-4$ & 62 \\
Moderately saline & $4-8$ & 25 \\
Strongly saline & $8-16$ & 0 \\
Very strongly saline & $>16$ & 0 \\
\hline
\end{tabular}

higher salinity in water will lead to higher salinity in paddy soil. This shows that the salinity in water in the paddy fields is the cause of the accumulation of salt content in the soil. The result from this study is consistent with those researches on the effects of salinity intrusion in the Red River and Mekong Delta regions (Ha et al. 2020; Yen et al. 2017). Fig 4 presents the mapping of the salinity levels of the soil in paddy fields that provide highly useful information for local policymakers and farmers about the status of salinity intrusion in paddy land. 
Factors Affecting the Salinity Intrusion at the Paddy Field in Thua Thien Hue Province, Vietnam

Table 5: Result of regression analysis for surface water and topsoil samples.

\begin{tabular}{|c|c|c|c|c|c|c|}
\hline & Parameter & Coefficient & Std. Err. & $p$-value & $\mathrm{n}$ & $\mathrm{R}^{2}$ \\
\hline \multirow[t]{5}{*}{ Surface water } & Distance & -0.023 & 0.001 & $<0.001^{* * *}$ & 175 & 0.9123 \\
\hline & Temperature & -0.067 & 0.272 & 0.807 & & \\
\hline & Rainfall & -0.001 & 0.002 & 0.552 & & \\
\hline & Humidity & -0.559 & 0.213 & $0.010^{* *}$ & & \\
\hline & Evaporation & -0.082 & 0.033 & $0.015^{\star *}$ & & \\
\hline \multirow[t]{5}{*}{ Topsoil } & Distance & -0.005 & 0.0002 & $<0.001^{* * *}$ & 175 & 0.8013 \\
\hline & Temperature & -0.053 & 0.101 & 0.599 & & \\
\hline & Rainfall & 0.001 & 0.001 & 0.467 & & \\
\hline & Humidity & -0.088 & 0.079 & 0.266 & & \\
\hline & Evaporation & -0.006 & 0.012 & 0.657 & & \\
\hline
\end{tabular}

Notes: $p$-value is significance level. ${ }^{* * *}$ represents $p<0.001 .{ }^{* *}$ represents $p<0.01 .{ }^{*}$ represents $p<0.05$.

\section{Factors influencing the salinity concentrations in the paddy field}

To quantify the factors influencing the salinity concentrations in the paddy field, we applied multiple regression analysis considering the distance from the salinity source, meteorological conditions including temperature, rainfall, humidity and evaporation rate.

For surface water, the regression result presented a significant inverse relationship between the salinity concentration and distance, humidity and evaporation rate. These findings are consistent with those researches on the meteorological factors affecting the salinity levels. Lam et al. (2014) concluded that salinity concentrations were higher at low elevations (from Tam Giang lagoon) than those concentrations at high elevations. Al-Shammiri (2002) found that a decrease in the evaporation rate led to an increase in the water salinity because of the reduction in the water vapor pressure at the water surface. High atmospheric humidity reduced the level of salinity (Nieman and Poulson, 1967). Temperature and rainfall tended to have an inverse relationship with salinity concentration (but insignificant statistics). For soil, only distance had a significant inverse relationship with the salinity concentration. Therefore, the distance from the salinity source is the most important factor affecting the salinity concentration in the paddy field.

\section{CONCLUSION}

The mean values of salinity concentrations of water and soil in the paddy field were relatively high with 9.7 (range: 0-23.5 $\mathrm{dS} \mathrm{m}^{-1}$ ) and $2.1 \mathrm{dS} \mathrm{m}^{-1}$ (range: 0-6.5 dS $\mathrm{m}^{-1}$ ), respectively. By simultaneously measuring water and soil salinity in paddy fields, we found a significantly positive correlation between water and soil salinity. This means that saline water may cause the accumulation of salt content into the soil. The distances from salinity sources, water from Tam Giang lagoon and shrimp pond were major factors affecting the salinity concentrations. We found that a significant inverse relationship between salinity concentrations of water $(r=-0.95 ; p<0.01)$ and soil $(r=$ $-0.89 ; p<0.01)$ and distance of salinity source. The concentrations of surface water within $1000 \mathrm{~m}$ from the salinity source were saline that might harm the paddy soil and rice production. Therefore, we highly recommend strict management when the rice cultivation activities take place at a distance of $1000 \mathrm{~m}$ from the Tam Giang lagoon and shrimp pond.

\section{ACKNOWLEDGEMENT}

This work was supported by the University of Agriculture and Forestry, Hue University fund (DHNL-TND-01). We thank the farmers in Phu Xuan commune and students for their cooperation in interviews, field data collection and experimental analysis.

\section{REFERENCES}

Abrol, I.P., Yadav, J.S.P., Massoud, F.I. (1988). Salt-affected Soils and their Management. FAO Soils Bulletin, vol. 39. Italy, Rome, p. 93.

Al-Shammiri, M. (2002). Evaporation rate as a function of water salinity. Desalination. 150: 189-203.

Baten, M.A., Seal, L., Lisa, K.S. (2015). Salinity Intrusion in Interior Coast of Bangladesh: Challenges to Agriculture in SouthCentral Coastal Zone. American Journal of Climate Change. 4: 248-262.

Ca, V.T., Vongvisessomjai, S., Asaeda, T. (1994). Study on salinity intrusion in the Red River Delta. Environmental Systems Research. 22: 213-218.

Dan, N.V., Hai, H.T., An, N.H. (2006). Results of Livelihood Analysis by Participatory Rural Appraisal in Quang Phuoc Commune 2006: Integrated Management of Lagoon Activities in Tam Giang Cau Hai Lagoon (IMOLA) Project. 1-8. People's Committee of Thua Thien Hue Province, Hue City, Vietnam.

Elayaraja, D., Sathiyamurthi, S. (2020). Influence of organic manures and micronutrients fertilization on the soil properties and yield of sesame (Sesamum indicum L.) in coastal saline soil. Indian Journal of Agricultural Research. 54: 89-94.

FAO (1988). In: Alexandratos N. (ed) World Agriculture Toward 2000: An FAO Study. London: Bellhaven Press, p. 338.

FAO (1992). In: The Use of Saline Waters for Crop Production. [Rhoades, J.D., Kandiah, A., Mashali, A.M.]. FAO Irrigation and Drainage Paper 48, Rome. 
Funakawa, S., Suzuki, R., Karbozova, E., Kosaki, T., Ishida, N. (2000). Salt-affected soils under rice-based irrigation agriculture in southern Kazakhstan. Geoderma. 97: 61-85.

Grattan, S.R., Zeng, L., Shannon, M.C., Roberts, S.R. (2002). Rice is more sensitive to salinity than previously thought. California Agriculture. 56(6): 189-198.

Ha, T.P., Kinh, N.A., Liou, Y.A., Phung, H.P., Hung, N.T. (2020). Estimation of salinity intrusion by using Landsat $8 \mathrm{OLI}$ Data in the Mekong delta, Vietnam. Progress in Earth and Planetary Science. 7: 1-16.

Lam, N.H., Watanabe, T., Funakawa, S. (2014). Spatiotemporal variability in soil salinity and its effects on rice (Oryza sativa L.) production in the north-central coastal region of Vietnam. Soil Science and Plant Nutrition. 60: 874-885.

Lam, N.H., Dong, T.P., Hoa, T.D. (2020). Path analysis for agronomic traits and yield of salt-tolerant rice cultivars under moderate salinity condition in Central Vietnam. Indian Journal of Agricultural Research. 54: 107-111.

Linh, N.H.K., Quy, L.N.P., Phuong, T.D.M., An N.T.B. (2017). Application of remote sensing and gis technology in mapping partition saline intrusion to paddy land: A case study at Phu Vang district, Thua Thien Hue Province. Journal of Agricultural Science and Technology, Hue University Journal of Science. 7: 48-59.

Mahesh, C.M., Ramovatar, M. (2019). Modified Ulaby model on backscattering as a function of salinity, frequency and soil moisture. Indian Journal of Agricultural Research. 53: 646-654.

Matthees, H.L., Yanbo, H., Owen, R.K., David, H., Deutsch, B., Lee, J., Clay, D.E., Reese, C., Malo, D.D., DeSutter, T.M. (2017). Predicting soil Electrical conductivity of saturation extract from a 1:1 soil to water ratio. Communication in Soil Science and Plant Analysis. 48: 2148-2154.

Minh, V.Q., Khoa, L.V., Tri, L.Q., Vu, P.T., Du, T.T. (2020). Limitation and recommendation for rice cultivation on the problem soils in the Southern Region of Vietnam. Indian Journal of Agricultural Research. 54: 617-622.
Nhung, T.T., Phu. L.V., Nghi, V.V., Bang, H.Q. (2019). Salt intrusion adaptation measures for sustainable agricultural development under climate change effects: A case of Ca Mau Peninsula, Vietnam. Climate Risk Management. 23: 88-100.

Nieman, R.H., Poulson, L.L. (1967). Interactive effects of salinity and atmospheric humidity on the growth of bean and cotton plants. Botanical Gazette. 128: 69-73.

Sambridge, M., Braun, J., McQueen, H. (1995). Geophysical parameterization and interpolation of irregular data using natural neighbors. Geophysical Journal International. 122: 837-857.

Sibson, R. (1981). A Brief Description of Natural Neighbor Interpolation. In: [Barnett, V., (Ed.)], Interpreting Multivariate Data. John Wiley and Sons: 21-36.

Trang, D.T.H., Amjath-Babu, T.S., Zander, P., Muller, K. (2019). Paddy in saline water: Analysing variety-specific effects of saline water intrusion on the technical efficiency of rice production in Vietnam. Outlook on Agriculture. 48(3): 237-245.

United Nations, (2020). Vietnam drought and saltwater intrusion in the Mekong delta. Joint Assessment Report. 15-17 January.

Wassmann, R., Hien, N.X., Hoanh, C.T., Tuong, T.P. (2004). Sea level rise affecting the Vietnamese Mekong Delta: water elevation in the flood season and implications for rice production. Climatic Change. 66: 89-107.

Yen, N.T.B., Kamoshita, A., Van, D.T.H., Matsuda, H., Kurokura, H. (2017). Salinity intrusion and rice production in Red River Delta under changing climate conditions. Paddy and Water Environment. 15: 37-48.

Zhang, H., Schroder, J.L., Pittman, J.J., Wang, J.J., Payton, M.E. (2005). Soil salinity using saturated paste and 1:1 soil to water extracts. Soil Science Society of America Journal. 69: 1146-1151. 